\title{
Analisis Dan Perancangan Aplikasi Pelayanan Publik Smart Rt/Rw Untuk Desa Terusan Kecamatan Sindang Kabupaten Indramayu
}

\author{
Fachrul Pralienka Bani Muhamad ${ }^{1}$, Munengsih Sari Bunga ${ }^{2}, \operatorname{Darsih}^{3}$, Firmansyah $^{4}$ \\ 1,2,3,4 Jurusan Teknik Informatika, Politeknik Negeri Indramayu \\ E-Mail:1 fachrul.pbm@gmail.com, ${ }^{2}$ nengslim85@gmail.com, ${ }^{3}$ darsih82@gmail.com, \\ ${ }^{4}$ firmanvsly@gmail.com
}

\begin{abstract}
ABSTRAK
Peran pengurus RT/RW tidak hanya sebagai pelayan publik yang bersifat administratif saja, tetapi juga sebagai pelayan kepentingan warga masyarakat secara lebih luas. Oleh karena itu, peran mereka perlu untuk dioptimalkan agar aspirasi warga dapat tertampung. Namun, luasnya wilayah dan padatnya jumlah penduduk seringkali membuat pengurus RT/RW terkendala dalam mempercepat akses pelayanan dan meningkatkan efektifitas kegiatannya. Peran teknologi informasi menjadi sangat penting, mengingat pemanfaatan teknologi telah banyak terbukti berhasil dalam meningkatkan pelayanan publik. Pemanfaatan suatu sistem informasi yang sudah ada belum tentu sesuai dengan kebutuhan dan kebijakan daerah terkait. Pada penelitian ini dilakukan pengembangan suatu sistem yang disesuaikan dengan kebutuhan dan kebijakan daerah, khususnya Desa Terusan, Kecamatan Sindang, Kabupaten Indramayu. Metode waterfall digunakan dalam pengembangan perangkat lunak yang sesuai dengan kebutuhan pengurus RT/RW desa tersebut. Dihasilkan sebuah aplikasi Smart RT/RW yang memiliki lima fitur utama, yaitu lapor kejadian, undangan kegiatan, pemungutan suara, transparansi dana, dan cetak laporan.
\end{abstract}

Kata kunci: aplikasi, kabupaten indramayu, pelayanan publik, smart rt/rw, teknologi informasi.

\begin{abstract}
The role of RT/RW management is not only as a public servant who regulates administration, but also as a servant of the wider community. Therefore, their role needs to be optimized so that citizens' aspirations can be accommodated. However, the vast area and the dense population succeeded in making the RT/RW management constrained in increasing access to services and increasing the effectiveness of their activities. The role of information technology is very important, given the technology that has proven successful in improving public services. Utilization of an existing information system is not in accordance with the needs and related local policies. In this study the development of a system that is tailored to the needs and regional policies, especially Terusan Village, Sindang District, Indramayu Regency. The waterfall method is used in software development that suits the needs of the village RT/RW managers. A Smart RT/RW application has five main features, which are report problem, event invitations, voting, funding transparency, and report generating.
\end{abstract}

Keywords: application, indramayu district, information technology, public services, smart rt/rw.

Author Korespondensi (Fachrul Pralienka Bani Muhamad)

Email :fachrul.pbm@gmail.com

\section{PENDAHULUAN}

Pelayanan publik yang baik kepada masyarakat perlu untuk dilakukan oleh seluruh tingkatan aparatur Pemerintah, baik di Pusat, Provinsi, Kota/Kabupaten, Kecamatan, hingga Desa atau Kelurahan. Pelayanan publik dari Pemerintah dituntut untuk lebih cepat, transparan, dan mudah, agar dapat meningkatkan rasa kepercayaan dan kenyamanan warga masyarakat [1]. Pada Undang-Undang (UU) Nomor 25 Tahun 2009 dijelaskan bahwa pelayanan publik adalah serangkaian kegiatan untuk memenuhi kebutuhan pelayanan yang sesuai dengan aturan pada UU untuk setiap warga negara dan penduduk atas barang, jasa, dan/atau pelayanan administratif yang diselenggarakan oleh pelayanan publik [2].

Pelayanan publik yang berkaitan langsung dengan kepentingan warga masyarakat dan paling mendasar adalah Rukun Tetangga atau Rukun Warga (RT/RW). Dengan wilayah yang luas dan jumlah penduduk yang cukup padat, 
maka jumlah RT umumnya dibagi menjadi lebih dari tiga, sehingga keberadaan RW menjadi penting dan diperlukan agar dapat mempercepat akses pelayanan dan efektivitas pelaksanaan kegiatan di wilayah RW tersebut [3]. Ketua RT/RW memegang peranan vital dalam terciptanya pelayanan publik yang baik. Keberadaan RT/RW sangat dibutuhkan pada semua kegiatan kemasyarakatan, karena RT/RW menjadi pelayan publik terdepan untuk warga masyarakat. Selain memberikan pelayanan publik kepada mereka, RT/RW berfungsi untuk melakukan koordinasi serta menjadi fasilitator pada kegiatan kewargaan tertentu.

Walaupun demikian, pelayanan publik masih kurang optimal mengingat kurangnya komunikasi atau timbal balik secara dua arah antara ketua RT/RW dan warga masyarakat. Bahkan peran mereka dianggap hanya sebatas melakukan peran-peran yang sifatnya administratif seperti pencatatan mutasi kependudukan, pembuatan surat-surat keterangan dalam membuat Kartu Tanda Penduduk (KTP) atau pelayanan persuratan lainnya [3]. Hal ini menjadi penting untuk diperhatikan, karena ketua RT/RW dapat melayani kepentingan warganya secara lebih luas, misalnya menerima aspirasi atau keluhan warga, mendeteksi permasalahan sosial lebih dini (kasus pencurian, narkoba, covid-19, gizi buruk, kerusakan tanggul, dan masalah lainnya). Selain itu, peran ketua RT/RW dapat membantu suasana pelaksanaan pemilihan langsung (PEMILU) menjadi lebih kondusif. Agar hal tersebut dapat tercapai, maka ketua RT/RW perlu berkoordinasi dengan warga di lingkungannya, serta menjembatani hubungan antar warga dalam membantu menangani permasalahan yang dihadapinya.

Beberapa penelitian sebelumnya telah dilakukan untuk membantu meningkatkan pelayanan publik [1], [4] [5] [6] [7]. Penelitian tersebut umumnya memanfaatkan peran teknologi informasi dalam meningkatkan pelayanan publik. Teknologi informasi memungkinkan proses pengolahan data (mencakup proses mendapatkan, menyusun, menyimpan, serta memanipulasi) dilakukan dengan cepat dan akurat, sehingga menghasilkan informasi yang berkualitas, dan dapat dipertanggungjawabkan untuk pengambilan keputusan. Media internet pun menjadi entitas yang tidak dapat dipisahkan, sehingga memungkinkan pelayan publik berinteraksi dengan warga masyarakat tanpa ada batasan ruang dan waktu [4].

Namun, produk penelitian sebelumnya belum tentu dapat diimplementasikan untuk daerah lain, dikarenakan perbedaan kebutuhan serta kebijakan daerah terkait. Pada penelitian ini, dilakukan observasi pada salah satu daerah di Kabupaten Indramayu, tepatnya di Desa Terusan Kecamatan Sindang. Berdasarkan hasil wawancara dengan ketua RT/RW. 07/03 didapatkan lima masalah utama dalam memberikan pelayanan publik kepada warganya yaitu transparansi dana, pemberitahuan informasi (undangan) kegiatan, pemungutan suara, lapor kejadian, dan cetak laporan.

Berdasarkan pemaparan masalah tersebut, maka pada penelitian ini diusulkan pengembangan produk teknologi informasi berbasis internet, aplikasi Smart RT/RW. Diharapkan, aplikasi ini dapat membantu peran ketua atau pengurus RT/RW di Desa Terusan Kecamatan Sindang Kabupaten Indramayu. Adapun improvement yang dilakukan pada penelitian ini yaitu penggunaan platform mobile dalam pengiriman data oleh masyarakat, karena warga cenderung memiliki mobilitas yang tinggi dan menuntut penggunaan aplikasi yang ringkas. Selain itu, aplikasi ini dapat melakukan penyeleksian data laporan masyarakat yang terindikasi duplikat, mengirimkan notifikasi setiap kali ada undangan atau jajak pendapat dari ketua RT/RW, dan menyediakan fitur transparansi dana.

\section{METODOLOGI}

Aplikasi Smart RT/RW dikembangkan dengan menggunakan model Waterfall. Karakteristik pada model tersebut mendukung pengembangan perangkat lunak dengan spesifikasi kebutuhan yang tidak dinamis [8], [9], [10]. Hal ini sejalan dengan kasus pengembangan Aplikasi Smart RT/RW. Proses pengembang dilakukan secara sequential atau berurutan dari tahap analisis kebutuhan, perancangan, pembuatan kode program, pengujian, deployment, hingga pemeliharaan. Adapun tahapan metodologi pada penelitian ini dapat dilihat pada Gambar 1. 


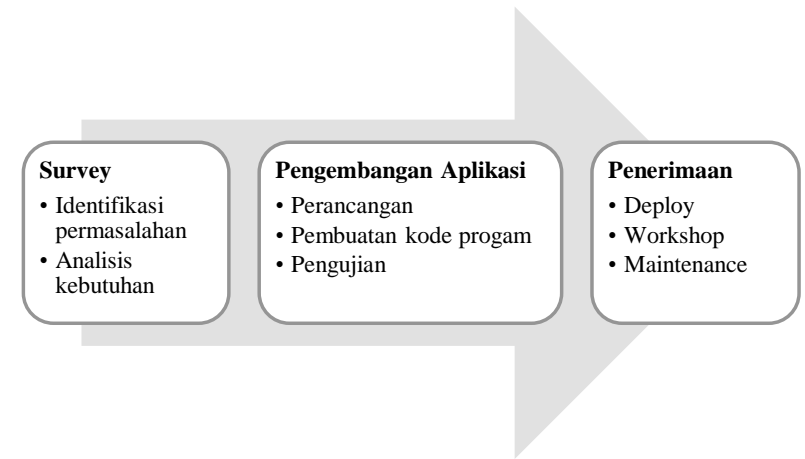

Gambar 1. Metodologi penelitian

Berdasarkan Gambar 1, ditunjukkan bahwa metode penelitian ini dibagi ke dalam tiga tahapan utama, yaitu survey, pengembangan aplikasi, dan penerimaan. Di tahap survey dilakukan identifikasi permasalahan yang ada di RT/RW 07/03 Desa Terusan Kecamatan Sindang Kabupaten Indramayu. Hasil identifikasi masalah tersebut selanjutnya dianalisis agar didapatkan kebutuhan perangkat lunak yang dapat dijadikan solusi atas permasalahan tersebut.

Di tahap selanjutnya, dilakukan perincian deskripsi perancangan aplikasi yang terdiri dari Use-case Diagram [11], [12], Activity Diagram [13], dan Entity-Relationship Diagram (ERD) [14]. Hasil dari rincian deskripsi tersebut dijadikan acuan pada tahap pembuatan kode program beserta pengujiannya. Jika hasil pengujian menunjukkan bahwa aplikasi telah sesuai dengan spesifikasi kebutuhan, maka tahap selanjutnya adalah deploy, yaitu pengiriman paket aplikasi ke lingkungan produksi.

Setelah tahapan tersebut selesai, calon pengguna yang terdiri dari pengurus $\mathrm{RT} / \mathrm{RW}$ beserta perwakilan warga melakukan uji coba pada suatu kegiatan workshop. Hal-hal yang berkaitan dengan panduan penggunaan aplikasi dijelaskan pada kegiatan tersebut agar mereka mengetahui cara penggunaan aplikasi serta fitur-fitur yang tersedia pada aplikasi. Adapun maintenance dimulai sejak kegiatan workshop selesai.

\section{HASIL DAN PEMBAHASAN}

Pada bagian ini dijelaskan mengenai hasil dan pembahasan dari implementasi metodologi penelitian yang diusulkan. Adapun sub-bab yang dicakup pada bagian ini terdiri dari identifikasi dan analisis masalah, analisis kebutuhan aplikasi, perancangan aplikasi, pembuatan kode program, pengujian, dan penerimaan aplikasi.

\subsection{Identifikasi dan Analisis Masalah}

Terdapat beberapa masalah utama yang ditemukan pada Desa Terusan khususnya RT/RW 07/03 Kecamatan Sindang Kabupaten Indramayu. Permasalahan tersebut didapatkan dari hasil observasi pada kegiatan kepengurusan RT/RW dan wawancara dengan Ketua RW 03. Adapun masalah utama pada desa tersebut yaitu transparansi dana, undangan kegiatan, pemungutan suara, lapor kejadian, dan cetak laporan.

Masalah pertama terkait dengan transparansi dana. Pengurus RT/RW berperan penting dalam penerimaan iuran dana masyarakat. Dana tersebut nantinya digunakan untuk keperluan masyarakat, misalnya untuk membayar petugas kebersihan, perbaikan fasilitas umum, kegiatan tujuh belasan, dll. Saldo dari iuran dana beserta pemanfaatannya perlu untuk diinformasikan juga kepada masyarakat, agar tingkat kepercayaan mereka tidak berkurang. Ketua RT/RW yang mewakilinya dalam hal ini adalah bendahara, perlu menyampikan informasi saldo dana pada setiap kesempatan pertemuan. Hal ini menjadi tidak praktis karena informasi saldo tersebut tidak dapat diberikan kepada warga secara cepat. Selain itu, pengurus RT/RW memerlukan usaha lebih dalam menyajikan data penggunaan dana iuran warga.

Untuk mengadakan pertemuan dengan warganya, pengurus RT/RW perlu membuat undangan dan membagikannya kepada seluruh perwakilan kepala keluarga. Umumnya, undangan tersebut dicetak pada media kertas, sehingga memerlukan anggaran khusus untuk mencetak undangan tersebut. Mengingat banyaknya perwakilan kepala keluarga yang akan diberikan undangan, maka hal ini menjadi tidak efisien. Selain itu, pengurus RT/RW juga perlu asisten untuk membantu membagikan undangan kegiatan atau pertemuan secara manual dengan berkeliling ke rumah-rumah warga. Penggunaan media kertas juga dianggap kurang efektif, karena rentan hilang atau rusak.

Pengurus RT/RW biasanya membuat undangan tersebut untuk mengajak masyarakat dalam berpartisipasi pada suatu kegiatan sosial dan musyawarah. Adapun kegiatan musyawarah di desa tersebut, seringkali tidak dihadiri oleh sebagian besar perwakilan kepala keluarga, mengingat sulitnya menentukan waktu musyawarah yang sesuai dengan waktu luang mereka (warga). Selain itu, aturan social 
distancing dan physical distancing juga bisa menghalangi kegiatan berkumpul untuk melakukan musyawarah.

Masalah lain yang dialami oleh pengurus RT/RW maupun warga masyarakat adalah pelaporan suatu kejadian atau penerimaan keluhan yang dialami warga. Berdasarkan hasil observasi dan wawancara, warga yang ingin melaporkan kejadian atau menyampaikan keluhan yang dialaminya, perlu menghubungi pengurus $\mathrm{RT} / \mathrm{RW}$ atau mendatanginya secara langsung. Hal ini menjadi tidak praktis dan dapat menghambat proses penyampaian laporan, mengingat kurangnya informasi yang diketahui warga mengenai kontak pengurus RT/RW yang aktif serta waktu luang mereka dalam menerima kedatangan warga.

Masalah terakhir yang ditemukan pada pengurus RT/RW yaitu pembuatan dokumen rekap laporan kejadian dari warga, rekap kegiatan, dan rekap buku kas, yang masingmasing perlu dibuat secara rutin setiap bulan dan per tahun. Dokumen tersebut digunakan sebagai bentuk pertanggungjawaban kepada Pemerintah yang menaunginya. Namun, dikarenakan kesibukan pengurus RT/RW dalam menjalankan perannya, seringkali membuat dokumen rekap laporan tersebut tidak terlaksana tepat waktu.

\subsection{Analisis Kebutuhan Aplikasi}

Berdasarkan hasil identifikasi dan analisis masalah tersebut, maka selanjutnya dilakukan analisis terhadap kebutuhan pengguna hingga menjadi kebutuhan fungsional maupun nonfungsional pada aplikasi. Adapun kebutuhan fungsional maupun non-fungsional aplikasi Smart RT/RW disajikan pada Tabel 1.

Tabel 1. Analisis kebutuhan aplikasi smart RT/RW Kebutuhan Aplikasi Smart/RW

\begin{tabular}{|c|c|}
\hline \multicolumn{2}{|c|}{ Kebutuhan Aplikasi Smart/RW } \\
\hline Fungsional & Non-Fungsional \\
\hline $\begin{array}{l}\text { 1. Smart RT/RW dapat } \\
\text { menginformasikan warga } \\
\text { terkait undangan kegiatan } \\
\text { dari ketua RT/RW }\end{array}$ & $\begin{array}{l}\text { 1. Smart RT/RW dapat } \\
\text { memberikan notifikasi } \\
\text { kegiatan kepada warga } \\
\text { secara realtime }\end{array}$ \\
\hline $\begin{array}{l}\text { 2. Smart RT/RW dapat } \\
\text { menampilkan rincian } \\
\text { informasi kegiatan } \\
\text { kewargaan }\end{array}$ & $\begin{array}{l}\text { 2. Smart RT/RW dapat } \\
\text { menyeleksi laporan } \\
\text { kejadian yang redundan } \\
\text { dari masyarakat secara }\end{array}$ \\
\hline $\begin{array}{l}\text { 3. Smart RT/RW dapat } \\
\text { menerima laporan kejadian } \\
\text { dari warga }\end{array}$ & $\begin{array}{l}\text { otomatis } \\
\text { 3. Smart RT/RW } \\
\text { menyediakan pilihan }\end{array}$ \\
\hline $\begin{array}{l}\text { 4. Smart RT/RW dapat } \\
\text { menampilkan saldo dan } \\
\text { rincian penggunaan dana } \\
\text { iuran warga }\end{array}$ & $\begin{array}{l}\text { rentang waktu per bulan } \\
\text { dan per tahun pada fitur } \\
\text { laporan }\end{array}$ \\
\hline 5. Smart RT/RW dapat & \\
\hline
\end{tabular}

\begin{tabular}{ll}
\hline \multicolumn{1}{c}{ Kebutuhan Aplikasi Smart/RW } \\
\hline Fungsional \\
\hline memfasilitasi kegiatan \\
pemungutan suara (polling) \\
6. Smart RT/RW menyediakan \\
fitur rekap laporan kejadian, \\
kegiatan warga, dan buku \\
kas \\
\hline
\end{tabular}

\subsection{Perancangan Aplikasi}

Setelah tahapan analisis kebutuhan aplikasi selesai dilakukan, selanjutnya dilakukan perancangan aplikasi berdasarkan kebutuhan fungsional dan non-fungsional. Pada bagian ini dijelaskan beberapa tahapan perancangan yang dilakukan pada proses pengembangan Aplikasi Smart RT/RW. Adapun jenis pemodelan yang digunakan pada tahap ini yaitu Use Case Diagram, Activity Diagram, dan Entity-relationship Diagram.

\section{a. Use Case Diagram}

Use Case Diagram digunakan untuk memodelkan suatu abstraksi mengenai bagaimana pengguna dapat berinteraksi dengan sistem. Selain itu, ditentukan pula langkah-langkah yang diperlukan dalam mencapai tujuan tersebut. Use Case Diagram dimodelkan sesuai dengan kebutuhan fungsional dan non-fungsional aplikasi Smart RT/RW.

Terdapat tiga aktor yang berinteraksi dengan aplakasi, yaitu pengurus RT/RW, bendahara, dan warga. Bendahara adalah pengurus RT/RW, di mana ia dapat berinteraksi dengan aplikasi untuk mengisi pemasukan dan pengeluaran dana iuran. Data uang kas (iuran dana) tersebut nantinya dapat dilihat oleh warga. Selain itu, melalui smart RT/RW warga juga dapat mengirimkan laporan kejadian kepada pengurus RT/RW tanpa harus tatap muka secara langsung. Pengurus RT/RW dapat menerima sajian laporan yang telah diproses secara otomatis agar tidak menampilkan laporan yang redundan atau duplikat. Hal ini dilakukan untuk mempermudah pengurus RT/RW dalam menyortir laporan kejadian.

Untuk menyederhanakan proses pengiriman undangan kegiatan kepada warga, maka melalui aplikasi Smart RT/RW, pengurus RT/RW dapat membuat undangan kegiatan yang mampu memberikan notifikasi kepada warga. Ada dua jenis notifikasi yang diterima warga, yaitu notifikasi undangan kegiatan dan notifikasi untuk melakukan pemungutan suara (polling). Agar warga dapat memperoleh notifikasi polling, pengurus RT/RW perlu untuk membuat pertanyaan polling terlebih dahulu. Selanjutnya, warga dapat 
mengirim polling tersebut melalui aplikasi Smart RT/RW berdasarkan pertanyaan yang diberikan pengurus RT/RW.

\section{b. Activity Diagram}

Proses perancangan selanjutnya adalah pembuatan Activity Diagram. Diagram ini membantu untuk mendeskripsikan perilaku alur kerja dan aspek dinamis dari sistem [13]. Pada tahap ini, activity diagram dibuat ke dalam empat activity, yaitu lapor kejadian, undangan kegiatan (notifikasi), polling online, dan transparansi dana. Rancangan activity diagram digunakan untuk menunjukkan bagaimana suatu objek berperilaku atas cara mereka berkolaborasi, baik secara sequential maupun parallel.

Aktifitas lapor kejadian diinisiasi oleh warga melalui aplikasi. Hal yang pertama kali perlu dilakukan adalah warga melakukan login terlebih dahulu untuk melakukan verifikasi pengguna. Pada halaman utama, warga memilih menu lapor kejadian dan mengisi rincian laporan tersebut. Setelah lapor kejadian dikirim, pengurus RT/RW mendapatkan notifikasi kejadian. Agar hubungan timbal balik dua arah atara warga dengan pengurus RT/RW berjalan dengan baik, maka tindak lanjut laporan tersebut dapat diinformasikan kembali kepada warga dengan mengunggah bukti foto. Selanjutnya, warga berhak menilai secara obyektif melalui rating hasi pekerjaan pengurus RT/RW.

Sedangkan untuk aktifitas undangan kegiatan, diinisiasi oleh pengurus RT/RW. Sama halnya dengan aktifitas lapor kejadian, pengguna perlu untuk melakukan verifikasi akun terlebih dahulu melalui proses login. Setiap kegiatan yang dibuat oleh pengurus RT/RW dapat dipublikasikan melalui aplikasi sehingga warga masyarakat dapat memperoleh notifikasi undangan tersebut.

Aktifitas pemungutan suara memungkinkan untuk dilakukan tanpa harus melakukan tatap muka. Aktifitas ini diinisiasi oleh pengurus RT/RW dalam membuat pertanyaan polling. Setelah pertanyaan dipublikasi, maka warga menerima notifikasi polling. Setiap suara yang diberikan oleh warga akan direkap aplikasi Smart RT/RW secara otomatis.

Aktifitas transparansi dana diinisiasi oleh bendahara. Setiap uang yang masuk ataupun keluar dari dan/ke dana warga, perlu untuk dicatat melalui aplikasi. Data riwayat aliran dana nantinya akan direkap secara otomatis oleh aplikasi Smart RT/RW dan diinformasikan kepada warga. Dengan demikian, warga dapat terus memantau penggunaan iuran dana mereka.

\section{c. Entity-relationship Diagram (ERD)}

Rancangan selanjutnya adalah ERD. Pada tahap ini dilakukan pemodelan data yang diperlukan untuk mendefinisikan obyek data beserta hubungannya dengan menggunakan notasi grafis dalam pengembangan aplikasi Smart RT/RW. Hal ini juga diperlukan agar tahap pengelolaan informasi menjadi lebih sederhana untuk dipelihara. Terdapat tiga belas entitas pada ERD aplikasi Smart RT/RW, yaitu login, perihal, rating, pertanyaan, warga, pendidikan, pekerjaan, polling, agama, jawaban, kegiatan, dan pengguna. Adapun rincian gambar ERD aplikasi Smart RT/RW disajikan pada Gambar 2. 


\subsection{Pembuatan Kode Program}

Tahapan selanjutnya adalah implementasi kode program berdasarkan rancangan yang telah dibuat. Terdapat dua platform yang digunakan untuk menjalankan ekosistem aplikasi Smart RT/RW, yaitu mobile-based dan web-based. Mobile-based dimanfaatkan untuk pengiriman data lapor kejadian dari warga. Tidak hanya itu, fitur kewargaan secara lebih efisien. Tidak hanya itu, warga pun dapat dengan lebih mudah melaporkan kejadian di sekitarnya, baik itu terkait fasilitas umum maupun layanan publik lainnya. Secara umum aplikasi ini dibagi menjadi lima fitur utama, yaitu lapor kejadian, undangan kegiatan, pemungutan suara (polling), transparansi dana, dan cetak laporan.

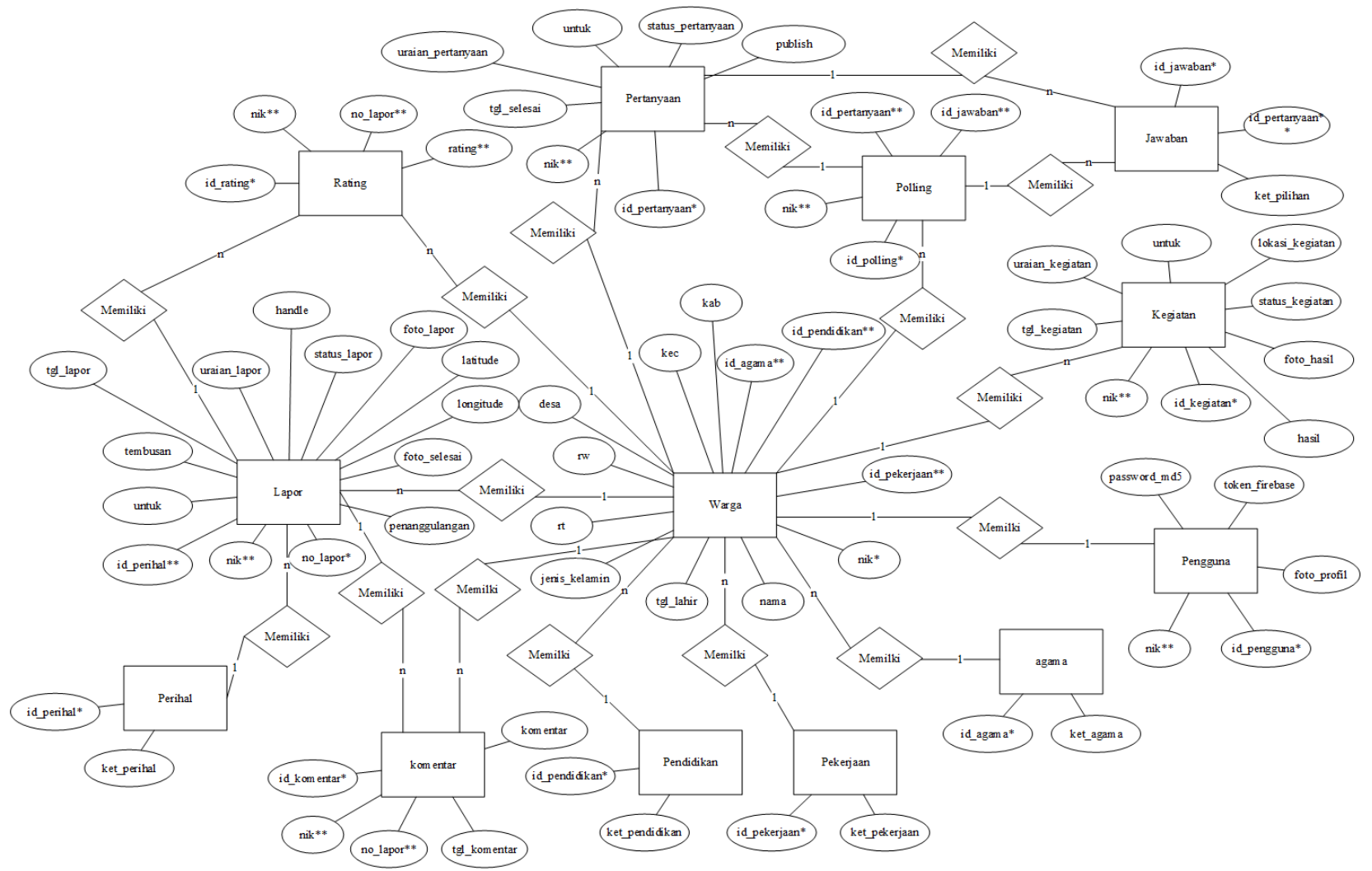

Gambar 2. Entity-Relationship Diagram (ERD) aplikasi Smart RT/RW

dasar mobile-based misalnya notifikasi dan sensor lokasi juga digunakan untuk memberikan informasi undangan dan menentukan titik laporan kejadian. Sedangkan pada web-based platform digunakan oleh Admin aplikasi Smart RT/RW dalam mengelola data utama. Adapun bahasa pemrograman yang digunakan untuk mengembangkan aplikasi yang berjalan di smartphone Android adalah Java. Sedangkan untuk aplikasi Web, digunakan bahasa pemrograman PHP. Selain itu, MySQL Database Management System (DBMS) digunakan untuk penyimpanan data.

Output yang dihasilkan pada tahap ini adalah produk teknologi informasi, aplikasi Smart RT/RW. Pengurus RT/RW yang terdiri dari ketua RW, beberapa ketua RT, dan bendahara dimungkinkan untuk mengelola kegiatan

\section{a. Fitur Lapor Kejadian}

Pada bagian ini dijelaskan mengenai fitur lapor kejadian pada aplikasi Smart RT/RW. Untuk menggunakan fitur ini warga yang akan melaporkan kejadian perlu untuk login. Hal ini dilakukan agar pengurus RT/RW mengetahui siapa pengguna yang melaporkan kejadian. Adapun data yang dilaporkan antara lain memuat data perihal lapor, uraian lapor, bukti foto, dan lokasi kejadian. Rincian antarmuka fitur lapor 
kejadian disajikan pada Gambar 3.

Gambar 3. Tampilan antarmuka fitur lapor kejadian pada aplikasi Smart RT/RW

Pada Gambar 3, dijelaskan bahwa warga dapat mengetahui semua lapor kejadian yang telah

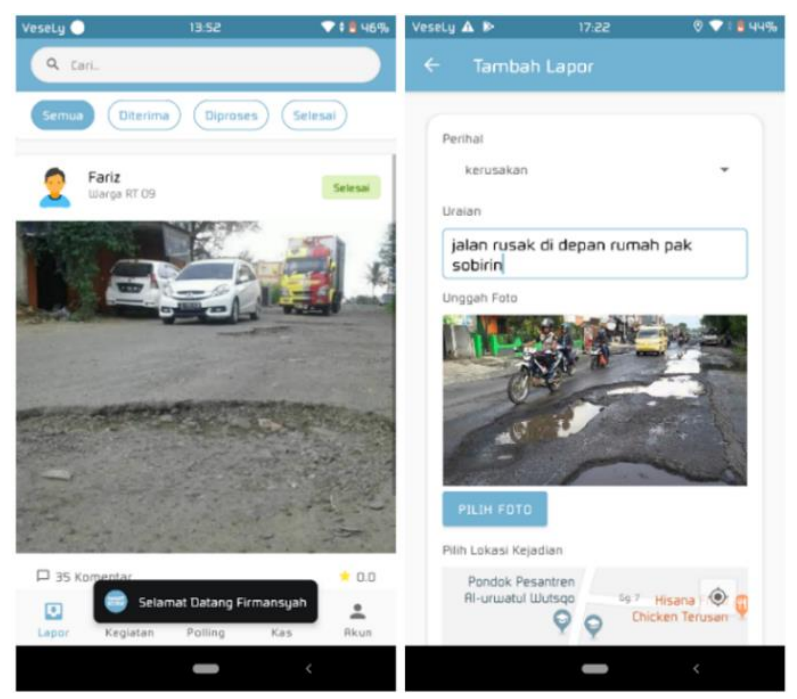

disampaikan warga untuk daerah RT yang sama. Lapor kejadian tersebut dapat diseleksi berdasarkan keseluruhan laporan, laporan yang telah diterima pengurus RT/RW, laporan yang sedang diproses atau ditindaklanjuti, dan laporan kejadian yang sudah berhasil ditangani atau selesai.

Pada antarmuka itu pula, disajikan lima fitur utama yang bisa diakses oleh warga, yaitu menu 'Lapor' untuk melaporkan kejadian, 'Kegiatan' untuk menampilkan daftar kegiatan yang akan datang, 'Polling' untuk menampilkan daftar polling yang berhak untuk diisi warga, 'Kas' untuk menampilkan informasi transparansi dana terkini, dan yang terakhir adalah 'Akun' untuk mengelola profil warga.

Setelah warga berhasil melaporkan kejadian, selanjutnya pengurus RT/RW mendapatkan notifikasi dan menerima laporan tersebut. Pihak pengurus RT/RW dapat memproses laporan tersebut dengan menekan tombol "diproses", untuk menandai bahwa laporan tersebut sedang diproses. Jika tindak lanjut laporan tersebut telah selesai dikerjakan, maka pengurus RT/RW mengkonfirmasi penyelesaian laporan dengan mengunggah foto sebagai bukti bahwa pekerjaan tersebut telah selesai. Tampilan antarmuka konfirmasi laporan dapat dilihat pada Gambar 4.

Pada Gambar 4, ditampilkan layar Aplikasi Smart RT/RW untuk pengurus RT/RW yang menerima laporan kejadian dari warganya. Hal yang ditampilkan antara lain rincian laporan dari warga beserta dua tombol eksekusi yaitu 'Diproses' dan 'Teruskan'. Tombol 'Diproses' artinya penanganan laporan kejadian tersebut dapat langsung diselesaikan di tingkat RT dan status lapor berubah menjadi diproses. Namun apabila laporan kejadian warga memerlukan keterlibatan RW, maka tombol 'Teruskan' yang harus dipilih.

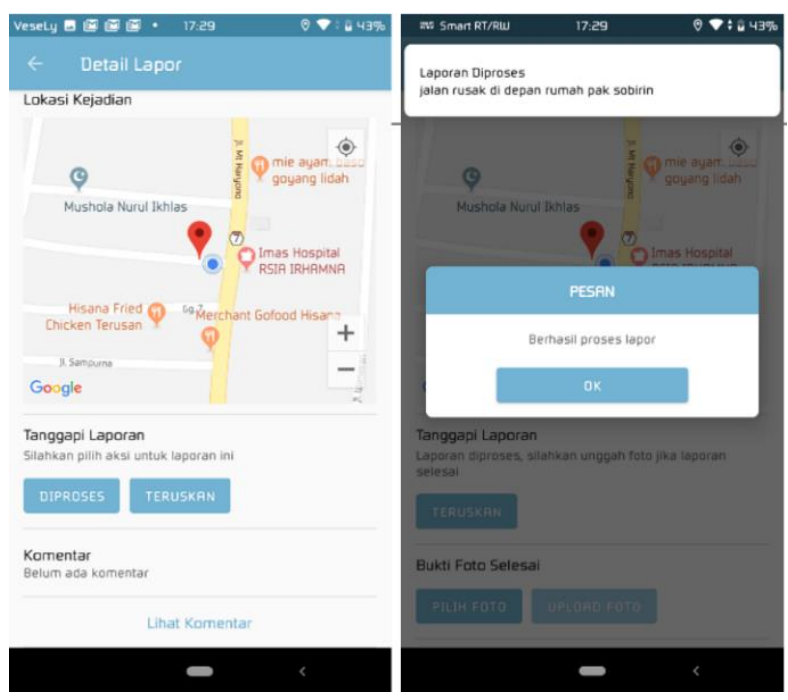

Gambar 4. Tampilan antarmuka konfirmasi lapor kejadian pada aplikasi Smart RT/RW

Untuk mengukur kepuasan warga terhadap tindak lanjut laporan mereka oleh pengurus RT/RW, maka aplikasi Smart RT/RW menyediakan fitur pemberian rating. Fitur ini hanya akan tersedia apabila pengurus RT/RW

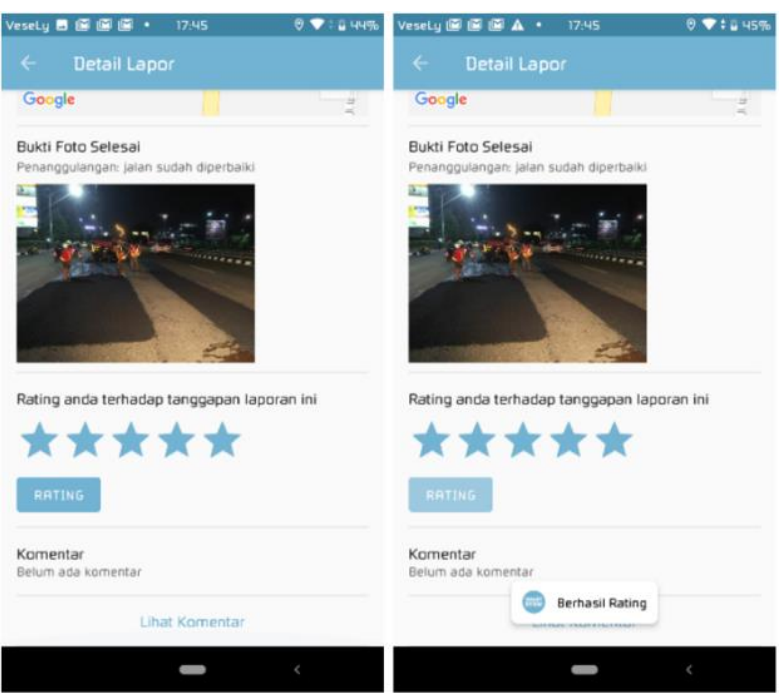

Gambar 5. Tampilan antarmuka rating penyelesaian lapor kejadian pada aplikasi Smart $\mathrm{RT} / \mathrm{RW}$ 
Telah menyelesaikan laporan warga. Rating tersebut tersedia per satu laporan warga. Adapun tampilan antarmuka timbal balik kepuasan warga terhadap penyelesaian lapor kejadian dapat dilihat pada Gambar 5.

Pada Gambar 5, warga dapat memberikan timbal balik atas kepuasan yang didapat atas hasil kinerja pengurus RT/RW. Pemberian nilai kepuasan mengimplementasikan skala likert, dimana semakin warga puas, maka rating yang dihasilkan semakin mendekati atau bahkan menjadi lima bintang.

\section{b. Fitur Undangan Kegiatan}

Fitur selanjutnya adalah undangan kegiatan dari pengurus RT/RW kepada warganya. Melalui aplikasi ini, mereka dimungkinkan untuk mengundang warganya tanpa harus mencetak undangan dan membagikannya ke seluruh kepala keluarga. Untuk memberikan undangan kepada warga, pengurus RT/RW hanya perlu mengisi data tanggal dan waktu kegiatan, uraian kegiatan, lokasi lapangan, dan seleksi warga. Tampilan antarmuka undangan kegiatan disajikan pada Gambar 6.

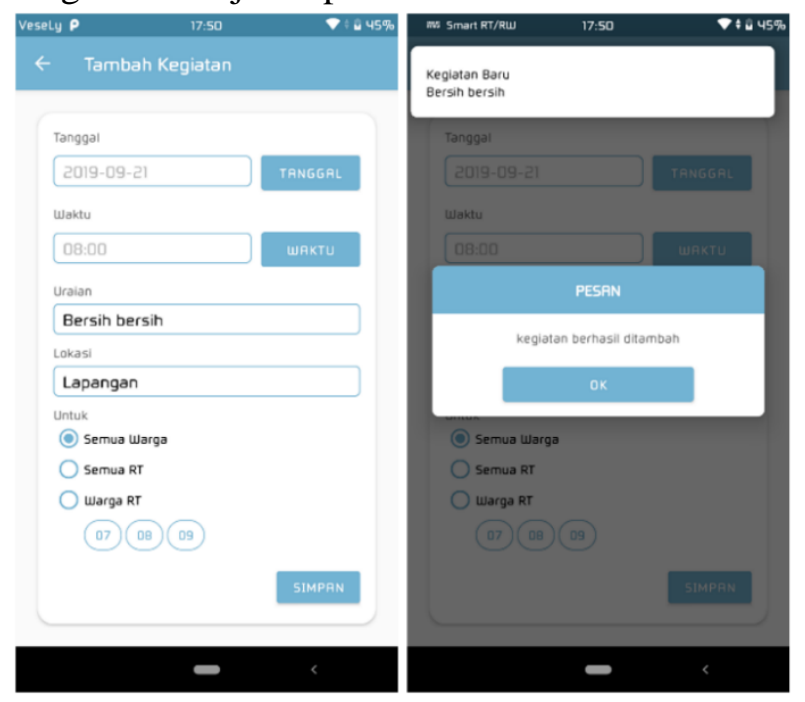

Gambar 6. Tampilan antarmuka undangan kegiatan pada aplikasi Smart RT/RW

Pada Gambar 6, untuk menambahkan kegiatan, pengurus RT/RW perlu menentukan tanggal dan waktu kegiatan terlebih dahulu, agar masyarakat dapat memperoleh notifikasi reminder kegiatan berdasarkan jadwal yang telah ditentukan. Jika jadwal kegiatan sudah ditentukan, maka isian yang perlu dilengkapi adalah uraian kegiatan, lokasi kegiatan, beserta seleksi warga yang akan mendapatkan notifikasi.

Selain itu, setiap kegiatan yang diusulkan pengurus RT/RW harus dapat terukur dan berdampak pada kebaikan warganya. Untuk memfasilitasi ukuran tersebut, maka pada aplikasi Smart RT/RW disediakan fitur tindak lanjut hasil kegiatan, yaitu bukti dan uraian hasil kegiatan setelah menyelesaikan kegiatan.

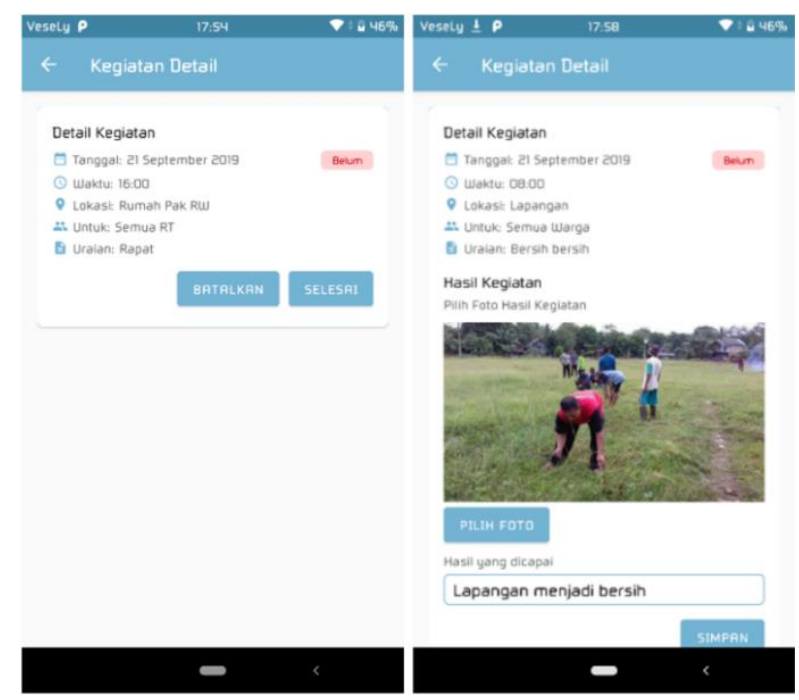

Gambar 7. Tampilan antarmuka penyelesaian kegiatan pada aplikasi Smart RT/RW

Pengguna yang berhak untuk mengisi hasil kegiatan adalah pengurus RT/RW yang menginisiasi kegiatan tersebut. Adapun gambar antarmuka penyelesaian kegiatan dapat dilihat pada Gambar 7.

Pada Gambar 7, dijelaskan bahwa setiap kegiatan yang telah diinisiasi oleh pengurus RT/RW dapat diselesaikan dengan informasi hasil. Jika pengurus RT/RW memilih tombol 'Selesai', maka bukti hasil kegiatan (foto) perlu diunggah, rincian hasil yang dicapai perlu untuk dilengkapi. Tombol 'Simpan' disentuh apabila semua isian telah dilengkapi.

\section{c. Fitur Pemungutan Suara}

Sebagai pelayan publik terdepan, Pengurus RT/RW perlu untuk selalu berkoordinasi dengan warga masyarakat untuk membuat suatu keputusan atau kebijakan terbaik. Untuk mendukung hal itu, aplikasi Smart RT/RW menyediakan fitur polling atau pemungutan suara secara online. Dengan begitu, proses mencapai mufakat dapat menjadi lebih efisien, 
baik dari pihak Pengurus RT/RW maupun warga. Gambar 8 menunjukkan empat tampilan antarmuka yang mewakili fitur pemungutan suara. Dua antarmuka pertama diisi oleh pengurus RT/RW, sedangkan sisanya diisi oleh warga.

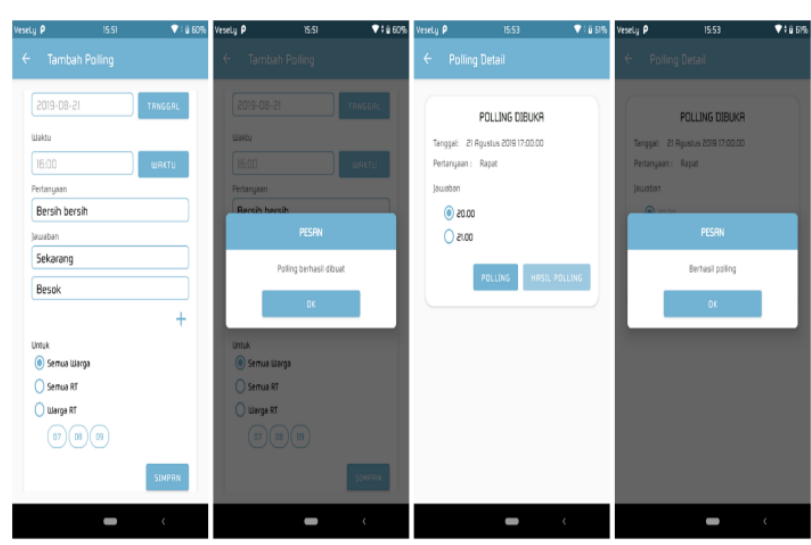

Gambar 8. Tampilan antarmuka pemungutan suara

Pada Gambar 8, dijelaskan bahwa pengurus RT/RW menginisiasi polling dengan membuat pertanyaan. Adapun isian yang harus dilengkapi yaitu tanggal dan waktu polling, uraian pertanyaan, pilihan jawaban, serta seleksi warga yang akan diberikan hak akses pemberian suara. Jika tombol simpan pada suatu polling disentuh, maka isian polling akan diperiksa secara otomatis kelengkapannya dan di-broadcast kepada warga berdasarkan seleksi warga yang dipilih. Penutupan polling dapat dilakukan secara manual atau otomatis berdasarkan waktu penutupan polling. Di sisi warga, pemberitahuan polling akan didapatkan apabila pengurus RT/RW telah mempublikasikan polling. Dengan demikian, warga dapat segera mengisi pilihan polling mereka tanpa harus datang langsung untuk mengikuti kegiatan musyawarah secara tatap muka.

\section{d. Fitur Transparansi Dana}

Fitur selanjutnya adalah transparansi dana. Fitur ini memungkinkan bendahara untuk mencatat semua arus kas, baik yang masuk maupun yang keluar. Bendahara dimungkinkan untuk meminimalisasi penggunaan media kertas dalam pencatatan arus kas. Proses penyimpanan informasi arus kas dilakukan dengan mengisi data tanggal pengisian, jumlah uang yang masuk/keluar, dan uraian dana tersebut. Jika bendahara berhasil menyimpan data melalui aplikasi, maka akan ada dialog yang tampil pada layar yang menginformasikan bahwa kas masuk/keluar berhasil disimpan. Setiap data yang tersimpan dapat dilihat oleh warga. Antarmuka fitur transparansi dana dapat dilihat pada Gambar 9.
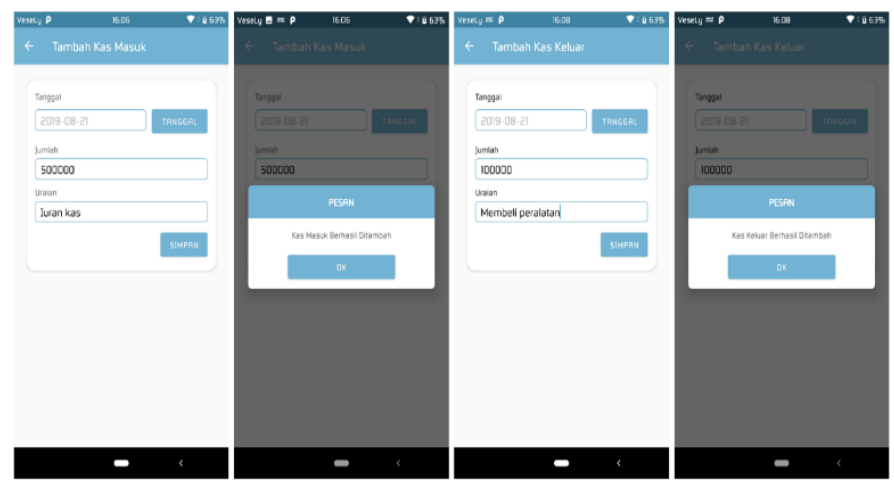

Gambar 9. Tampilan antarmuka transparansi dana

\section{Fitur Cetak Laporan}

Fitur yang terakhir adalah cetak laporan. Laporan yang dapat dihasilkan dari aplikasi ini terbagi menjadi tiga jenis, yaitu laporan kejadian, laporan buku kegiatan, dan laporan buku kas pembantu. Ketiga laporan tersebut dibuat berdasarkan format laporan Ketua RW kepada Pemerintah Kabupaten Indramayu. Fitur cetak laporan dapat diakses melalui aplikasi web.

1. Laporan Kejadian

Untuk mendapatkan hasil cetak laporan kejadian, pengguna perlu menyeleksi rentang waktu berdasarkan bulan, tahun, dan RT tertentu. Gambar 10 menunjukkan antarmuka cetak laporan kejadian.

2. Laporan Buku Kegiatan

Sama halnya dengan laporan kejadian, cetak buku kegiatan juga perlu parameter rentang waktu tertentu. Data yang disajikan pada laporan ini yaitu waktu kegiatan, uraian kegiatan, hasil yang dicapai, dan lokasi kegiatan (lihat Gambar 11).

3. Laporan Buku Kas Pembantu

Adapun hasil cetak laporan buku kas pembantu dapat dilihat pada Gambar 12 . Pada laporan tersebut terdapat perbandingan antara arus kas masuk dan arus kas keluar. 


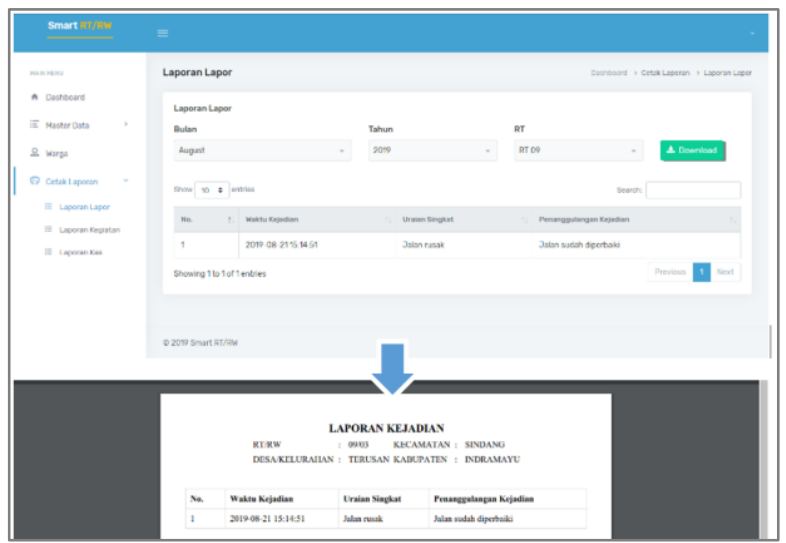

Gambar 10. Tampilan antarmuka cetak laporan kejadian pada aplikasi Smart RT/RW

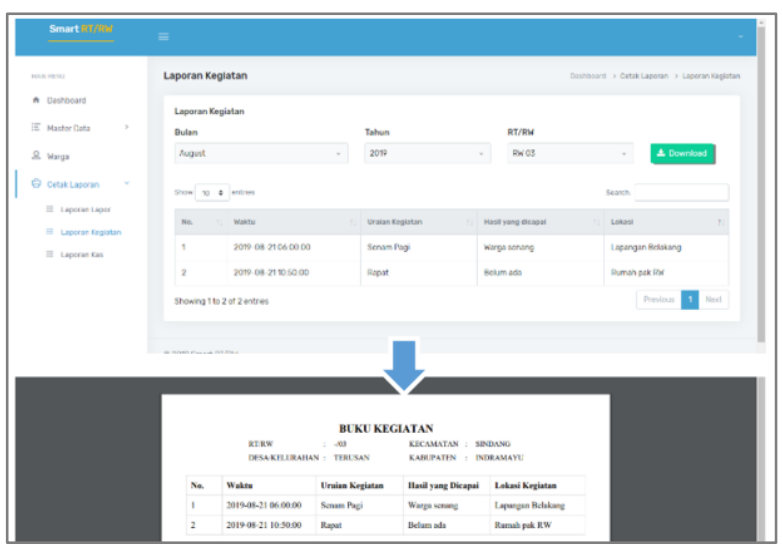

Gambar 11. Tampilan antarmuka cetak buku kegiatan pada aplikasi Smart RT/RW

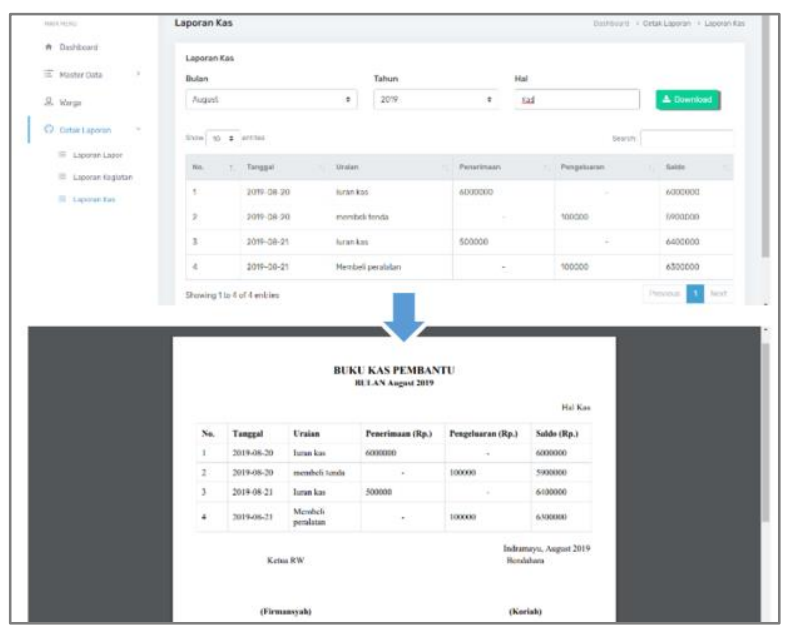

Gambar 12. Tampilan antarmuka cetak buku kas pembantu pada aplikasi Smart RT/RW

\subsection{Pengujian Aplikasi}

Setelah kode program berhasil dibuat, selanjutnya dilakukan pengujian. Model pengujian yang diimplementasikan pada pengembangan aplikasi Smart RT/RW adalah Black-box [15]. Sejumlah Langkah-langkah pada setiap penggunaan fitur dibuat menjadi suatu skenario berdasarkan use-case. Setiap output akan diperiksa, apakah sudah sesuai dengan ekspektasi atau belum. Pengujian ini dilakukan oleh kedua belah pihak, baik pengembang maupun calon pengguna. Pengembang menguji aplikasi saaat aplikasi masih berjalan pada lingkungan pengembangan, sedangkan calon pengguna menguji aplikasi ketika aplikasi sudah di-deploy ke lingkungan produksi.

Pada tahap pengujian ini, dilakukan sembilan (9) skenario yang berbeda di mana masing-masing skenario tersebut mewakili setiap kebutuhan perangkat lunak, baik yang fungsional maupun non-fungsional. Berdasarkan hasil pengujian, dihasilkan delapan skenario yang sesuai dengan kebutuhan, sedangkan satu sisanya masih belum sesuai. Adapun rekap hasil analisis pengujian disajikan ke dalam Tabel 2.

Tabel 2. Rekap analisis hasil pengujian aplikasi Smart RT/RW

\begin{tabular}{|c|c|c|}
\hline Kebutuhan & Skenario & Hasil Pengujian \\
\hline $\begin{array}{l}\text { 1. Smart RT/RW } \\
\text { dapat } \\
\text { menginformasikan } \\
\text { warga terkait } \\
\text { undangan } \\
\text { kegiatan dari } \\
\text { ketua RT/RW }\end{array}$ & $\begin{array}{l}\text { Pengurus } \\
\text { RT/RW } \\
\text { membuat } \\
\text { undangan } \\
\text { kegiatan } \\
\text { kewargaan baru }\end{array}$ & $\begin{array}{l}\text { Aplikasi berhasil } \\
\text { menampilkan } \\
\text { notifikasi } \\
\text { undangan kegiatan } \\
\text { kepada warga }\end{array}$ \\
\hline $\begin{array}{l}\text { 2. Smart RT/RW } \\
\text { dapat } \\
\text { menampilkan } \\
\text { rincian informasi } \\
\text { kegiatan } \\
\text { kewargaan } \\
\end{array}$ & $\begin{array}{l}\text { Pengurus } \\
\text { RT/RW } \\
\text { membuat } \\
\text { beberapa } \\
\text { kegiatan } \\
\text { kewargaan }\end{array}$ & $\begin{array}{l}\text { Aplikasi berhasil } \\
\text { menampilkan list } \\
\text { kegiatan } \\
\text { kewargaan beserta } \\
\text { rinciannya }\end{array}$ \\
\hline $\begin{array}{l}\text { 3. Smart RT/RW } \\
\text { dapat menerima } \\
\text { laporan kejadian } \\
\text { dari warga }\end{array}$ & $\begin{array}{l}\text { Warga } \\
\text { mengirimkan } \\
\text { laporan kejadian }\end{array}$ & $\begin{array}{l}\text { Aplikasi berhasil } \\
\text { menampilkan } \\
\text { informasi rinci } \\
\text { kejadian warga }\end{array}$ \\
\hline $\begin{array}{l}\text { 4. Smart RT/RW } \\
\text { dapat } \\
\text { menampilkan } \\
\text { saldo dan rincian } \\
\text { penggunaan dana } \\
\text { iuran warga } \\
\end{array}$ & $\begin{array}{l}\text { Bendahara } \\
\text { memperbarui } \\
\text { informasi dana } \\
\text { kas masuk dan } \\
\text { kas keluar }\end{array}$ & $\begin{array}{l}\text { Aplikasi berhasil } \\
\text { menampilkan } \\
\text { saldo kas terkini }\end{array}$ \\
\hline \multirow{2}{*}{$\begin{array}{l}\text { 5. Smart RT/RW } \\
\text { dapat } \\
\text { memfasilitasi } \\
\text { kegiatan } \\
\text { pemungutan suara } \\
\text { (polling) }\end{array}$} & $\begin{array}{l}\text { Pengurus } \\
\text { RT/RW } \\
\text { membuat polling } \\
\text { baru }\end{array}$ & $\begin{array}{l}\text { Aplikasi berhasil } \\
\text { menampilkan } \\
\text { notifikasi polling } \\
\text { kepada warga }\end{array}$ \\
\hline & $\begin{array}{l}\text { Warga } \\
\text { mengirimkan } \\
\text { pilihan polling } \\
\text { mereka }\end{array}$ & $\begin{array}{l}\text { Aplikasi di } \\
\text { pengurus RT/RW } \\
\text { berhasil } \\
\text { menerima dan } \\
\text { merekap jawaban } \\
\text { warga }\end{array}$ \\
\hline $\begin{array}{l}\text { 6mart RT/RW } \\
\text { menyediakan fitur } \\
\text { rekap laporan } \\
\text { kejadian, kegiatan } \\
\text { warga, dan buku } \\
\text { kas }\end{array}$ & $\begin{array}{l}\text { Ketua RW } \\
\text { menginisiasi } \\
\text { pembuatan } \\
\text { laporan rekap } \\
\text { kejadian, } \\
\text { kegiatan, dan } \\
\text { buku kas } \\
\text { berdasarkan }\end{array}$ & $\begin{array}{l}\text { Aplikasi berhasil } \\
\text { menghasilkan } \\
\text { laporan rekap } \\
\text { kejadian, kegiatan, } \\
\text { dan buku kas di } \\
\text { bulan Agustus } \\
2019\end{array}$ \\
\hline
\end{tabular}




\begin{tabular}{|c|c|c|}
\hline Kebutuhan & Skenario & Hasil Pengujian \\
\hline & $\begin{array}{l}\text { rentang waktu } \\
\text { bulan Agustus } \\
2019\end{array}$ & \\
\hline 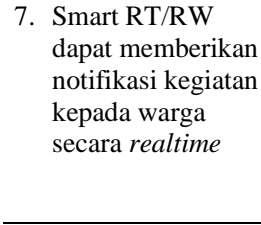 & $\begin{array}{l}\text { Pengurus } \\
\text { RT/RW } \\
\text { membuat } \\
\text { undangan } \\
\text { kegiatan dan } \\
\text { pemungutan } \\
\text { suara }\end{array}$ & $\begin{array}{l}\text { Aplikasi berhasil } \\
\text { menampilkan dua } \\
\text { notifikasi baru } \\
\text { yaitu undangan } \\
\text { kegiatan dan } \\
\text { pemungutan suara }\end{array}$ \\
\hline $\begin{array}{l}\text { 8. } \\
\text { Smart RT/RW } \\
\text { dapat menyeleksi } \\
\text { laporan kejadian } \\
\text { yang redundan } \\
\text { dari masyarakat } \\
\text { secara otomatis }\end{array}$ & $\begin{array}{l}\text { Dua warga yang } \\
\text { berbeda } \\
\text { menyampaikan } \\
\text { laporan kejadian } \\
\text { yang sama tetapi } \\
\text { dengan uraian } \\
\text { yang berbeda }\end{array}$ & $\begin{array}{l}\text { Aplikasi gagal } \\
\text { dalam } \\
\text { mengidentifikasi } \\
\text { kesamaan dua } \\
\text { laporan tentang } \\
\text { hal yang sama }\end{array}$ \\
\hline $\begin{array}{l}\text { 9. Smart RT/RW } \\
\text { menyediakan } \\
\text { pilihan rentang } \\
\text { waktu per bulan } \\
\text { dan per tahun } \\
\text { pada fitur laporan }\end{array}$ & $\begin{array}{l}\text { Ketua RW } \\
\text { menginisiasi } \\
\text { pembuatan } \\
\text { laporan rekap } \\
\text { kejadian, } \\
\text { kegiatan, dan } \\
\text { buku kas } \\
\text { berdasarkan } \\
\text { rentang waktu } \\
\text { bulan Agustus } \\
2019 \text { dan semua } \\
\text { bulan di tahun } \\
2019 \\
\end{array}$ & $\begin{array}{l}\text { Aplikasi berhasil } \\
\text { menghasilkan } \\
\text { laporan rekap } \\
\text { kejadian, kegiatan, } \\
\text { dan buku kas di } \\
\text { bulan Agustus } \\
2019 \text { dan semua } \\
\text { bulan di tahun } \\
2019\end{array}$ \\
\hline
\end{tabular}

\section{SIMPULAN DAN SARAN}

Berdasarkan hasil penelitian, dapat disimpulkan bahwa secara umum kebutuhan pelayanan publik pada Desa Terusan, khususnya RW 03 sudah berhasil dipenuhi. Adapun hal yang masih belum dicakup adalah penyeleksian secara otomatis terhadap lapor kejadian warga yang terindikasi duplikat. Walaupun demikian, hal tersebut dapat disiasati dengan kegiatan workshop atau penyuluhan yang mengajak warga agar tidak melaporkan kejadian yang sama. Keberhasilan aplikasi Smart RT/RW bergantung pada kerja sama yang baik antara pengurus RT/RW dan warganya.

Sebagai saran, pengembangan aplikasi Smart RT/RW perlu menerapkan metode semantik yang dapat mengidentifikasikan duplikasi laporan kejadian warga. Hal tersebut perlu dilakukan agar pengurus RT/RW dapat fokus pada suatu penyelesaian. Selain itu, perlu adanya kerja sama yang kuat dengan pihak Pemerintah Kabupaten atau Kota, sehingga laporan ketua RW dapat diketahui oleh pemegang kebijakan yang lebih luas secara cepat.

\section{REFERENSI}

[1] M. Khafid and A. Wahyudin, "Penyusunan dan Implementasi Sistem Pelayanan Publik Surat Pengantar RT/RW Online Untuk
Mewujudkan Semarang 'Smart City,", Rekayasa, vol. 16, no. 2, pp. 209-218, 2018.

[2] Y. F. Setyobudi, "Peran Masyarakat Dalam Pelayanan Publik Sesuai Dengan UndangUndang No . 25 Tahun 2009 Tentang Pelayanan Publik," no. 25. Batam, pp. 1-9, 2014.

[3] T. Widodo, W. Utomo, and B. Miranti, "Pengembangan Kapasitas Rukun Tetangga/Rukun Warga Sebagai Organisasi 'Akar Rumput' Dalam Era Desentralisasi Luas," J. Ilmu Adm. Media Pengemb. Ilmu dan Prakt. Adm., vol. 6, no. 1, pp. 18-33, 2009.

[4] R. H. Pratama, A. Hakim, and M. Shobaruddin, "Pelayanan Publik Berbasis Teknologi Informasi dan Komunikasi (TIK), Elektronik Rukun Tetangga/Rukun Warga (eRT/RW), Studi e-Government di Kelurahan Ketintang Kecamatan Gayungan Pemerintah Kota Surabaya," J. Adm. Publik, vol. 3, no. 12, pp. 2128-2132, 2009.

[5] E. Dewi, S. Mulyani, R. A. Wiyono, and J. T. Informatika, "Sistem Informasi Warga (SIMWARGA) Tingkat RT/RW Berbasis Web," Semin. Nas. Pengabdi. pada Masy., pp. 447-454, 2019.

[6] T. Rachmawati, "Smart Environment Program , Smart Way to Smart City," Policy Gov. Rev., vol. 1, no. 1, pp. 26-36, 2017.

[7] C. Series, "E-government strategy of Surabaya city government through e-rt / rw to improve the quality of public service," in International Joint Conference on Science and Technology, 2017.

[8] A. Alshamrani and A. Bahattab, "A Comparison Between Three SDLC Models Waterfall Model, Spiral Model, and Incremental/Iterative Model," Int. J. Comput. Sci. Issues, vol. 12, no. 1, pp. 106-111, 2015.

[9] M. Kuhrmann, M. Felderer, O. Linssen, and C. R. Prause, "Hybrid Software and System Development in Practice: Waterfall, Scrum, and Beyond," in International Conference on Software System Process, 2017.

[10] R. Stephens, Beginning software engineering. John Wiley \& Sons, 2015.

[11] N. Khurana, R. S. Chhillar, and U. Chhillar, "A Novel Technique for Generation and Optimization of Test Cases Using Use Case, Sequence , Activity Diagram and Genetic Algorithm," J. Softw., vol. 11, no. 3, pp. 242250, 2015. 
[12] A. Y. Aleryani, "Comparative Study between Data Flow Diagram and Use Case Diagram," Int. J. Sci. Res. Publ., vol. 6, no. 3, 2016.

[13] A. K. Jena, "A Novel Approach for Test Case Generation from UML Activity Diagram," in International Conference on Issues and Challenges in Intelligent Computing Techniques (ICICT), 2014, pp. 621-629.
[14] J. Frantiska, Entity Relationship Diagram. Visualization Tools for Learning Environment Development. Springer, 2018.

[15] H. Bhasin, E. Khanna, and Sudha, "Black Box Testing based on Requirement Analysis and Design Specifications," Int. J. Comput. Appl., vol. 87, no. 18, 2016. 